\title{
O (in)efetivo acesso à justiça no emprego público
}

\section{The (in)effective access to justice in public employment law}

\author{
Ana Rita Mesquita Babo Teixeira Pinto; \\ ${ }^{1}$ E-mail: babo.ana14@gmail.com \\ Técnica Superior Jurista| \\ Banco de Portugal
}

Resumo: Qualquer relação jurídico-laboral com vínculo de emprego público comporta, sempre, para ambos os contraentes, uma complexidade de direitos e obrigações, à semelhança do que acontece no direito privado. Neste tipo de relações jurídicas, o acesso aos tribunais torna-se fulcral até porque, muitas vezes, poderácolocar-se em causa o respeito por direitos fundamentais. Daí que neste ramo do direito, o acesso à justiça tenha que ser, acima de tudo, efetivo. Alcançaremos uma justiça efetiva, de maior qualidade, se as pretensões trazidas a juízo forem julgadas por tribunais especializados, com recursos humanos vocacionados e sensibilizados para determinado tipo de questões jurídicas. E será isso que efetivamente acontece nos litígios que emergem das relações públicolaborais? Serão os tribunais administrativos e fiscais os mais competentes para os conhecer, dirimir e julgar? Ou, pelo contrário, serão os juízos de trabalho mais capazes e competentes para lidar com estas matérias?

Palavras-chave: emprego público; justiça efetiva; competência dos tribunais; conflitos de jurisdição.

Abstract: Any public employment relationship contains, for both parts, a complexity of rights and duties (as it happens in the private labor sector). In these type of relationships, the access to justice becomes essential, particularly because litigation may involve fundamental rights violations'. In this area of law, the access to justice needs to be especially effective. To be more effective and provide better judgments, the litigation may be ruled by specialized courts with human resources aimed to judge specific legal issues. Is this what happens in the Portuguese legal proceedings that emerge from the public employment law? Are the Portuguese administrative courts the most competent ones to judge the litigation related to public employment? Or, in contrast, are labor courts more qualified to deal with these issues?

Keywords: public employment; effective justice; court jurisdiction; conflicts of jurisdiction. 


\section{pontěditora}

\section{Introdução}

Qualquer relação jurídica laboral (seja de natureza pública ou privada) comporta sempre, para ambos os contraentes (empregador/entidade pública e colaborador/colaborador com vínculo de emprego público), uma complexidade de obrigações e direitos. Este tipo de relação jurídicaacaba por incidir, grande parte das vezes, sobre direitos fundamentais, ${ }^{1}$ desde o mais básico direito à segurança no emprego, ${ }^{2}$ ao direito ao trabalho. ${ }^{3}$

Consequentemente, o acesso aos tribunais ${ }^{4}$ torna-se fulcral e a via mais adequada para uma defesa sólida e robusta perante violações de direitos fundamentais, tal como reconhecem Gomes Canotilhoe Vital Moreira (2014, p. 408) "O direito de acesso ao direito e à tutela jurisdicional efetiva ( $n^{\circ} 1$ e epigrafe) é, ele mesmo, um direito fundamental constituindo uma garantia imprescindível de proteção de direitos fundamentais, sendo, por isso, inerente à ideia de Estado de direito". Este acesso ao direito tem que se traduzir numa justiça efetiva. Ora, essa efetividade pode manifestar-se sob os mais variados aspetos. Um deles é, sem dúvida, serem proferidas sentenças adequadas às pretensões de tutela deduzidas em juízo. Na verdade, alcançaremos uma justiça de maior qualidade se as pretensões trazidas a juízo forem julgadas por tribunais especializados e com recursos humanos vocacionados e sensibilizados para determinado tipo de questões jurídicas. E será isso que efetivamente acontece nos litígios emergentes do direito de emprego público? Ao refletir sobre estão questão, deparamo-nos com alguns problemas que surgem nesta área e que pretendemos ver aqui tratados, equacionados e refletidos. Nomeadamente, questionamo-nos se serão os tribunais administrativos e fiscais (TAF) os mais competentes para conhecer de litígios emergentes de relações laborais no âmbito do emprego público. Ou, pelo contrário, até que ponto a justiça alcançaria decisões mais razoáveis se fossem os juízos de trabalho a conhecer e julgar estas matérias?

\section{A Lei Geral do Trabalho em Funções Públicas: principais alterações}




\section{pontěditora}

A Lei $n^{\circ}$ 35/2014, de 20 de junho, denominada Lei Geral do Trabalho em Funções Públicas (daqui em diante LGTFP), trouxe inúmeras mudanças para o direito do emprego público. Sem dúvida que a primeira alteração passa pela nova sistematização das matérias. A LGTFP possui um "intuito marcadamente agregador, no sentido de que pretende reunir num único diploma temáticas até agora dispersas por diversas diplomas” (Miguel Lucas Pires, 2016, p.5). Mais do que isso, a LGTFP também pretendeu integrar e contemplar as alterações legislativas realizadas no regime laboral da função pública,que, entretanto, o haviam descaracterizado por completo, devolvendo e reforçando também neste aspeto, a sua sistematização, unidade e coerência. Isso mesmo foi reconhecido na exposição de motivos da Proposta de Lei n. ${ }^{\circ}$ 184/XII, "A complexidade e proliferação de diplomas que regulam o regime de trabalho em funções públicas bem como as alterações avulsas e sucessivas de que o mesmo foi objeto[...] criaram um edifício legal que se vira contra a própria Administração Pública" que "propicia a conflituosidade jurídica, em grande parte derivada do seu carácter disperso e fragmentado, gerador de incerteza e insegurança na aplicação do direito."

Em segundo lugar importa destacar que a LGTFP pretendeu também tomar como "modelo de vínculo de emprego público a figura do contrato de trabalho em funções públicas, sem deixar de procurar um regime unitário para as duas grandes modalidades de vínculo de emprego (contrato e nomeação), realçando apenas as especificidades de cada uma sempre que necessário”(Cláudia Sofia Henriques Nunes, 2014, p.12).Sobre isso há que dar algumas notas breves, mas importantes.

O vínculo do emprego público é definido, no número 2 do artigo $6^{\circ}$ da LGTFP, como aquele pelo qual uma pessoa singular presta a sua atividade a um empregador público, de forma subordinada e mediante remuneração, podendo ser constituído por um tempo indeterminado ou a termo resolutivo. ${ }^{5}$ A par do contrato de trabalho, encontramos como modalidades de constituição do vínculo de emprego público, a nomeação e a comissão de serviço, ${ }^{6}$ com a diferença do primeiro, ao contrário dos restantes, se consubstanciar num ato bilateral celebrado entre um empregador público (com ou sem personalidade jurídica, agindo em nome e representação do Estado) e um particular, nos termos do qual se constitui uma relação de trabalho subordinado.

Decorre agora expressamente do artigo $7^{\circ}$ da LGTFP que "O vínculo do emprego público constitui-se, em regra, por contrato de trabalho em funções públicas”. Mantém-se assima tendência criada pela Lei dos Vínculos, Carreiras e Remunerações (LVCR), ${ }^{7}$ que introduziu 


\section{ponteditora}

uma mudança radical no regime do emprego público já que, até à sua entrada em vigor, a nomeação era a modalidade mais frequente de constituição de vínculo de emprego público. Acontece que a LGTFP não identifica, ao contrário do que sucede com a nomeação e a comissão de serviço, que funções públicas devem ser desempenhadas ao abrigo da celebração de um contrato de trabalho em funções públicas.

Pelo que, a sua constituição ainda que seja atualmente regra geral,acaba por ser atribuída subsidiariamente, o mesmo é dizer, será celebrado um contrato de trabalho em funções públicas, sempre que os trabalhadores não tenham sido nomeados ou não estejam abrangidos por uma comissão de serviço.

E quando é que as funções públicas têm que ser exercidas por nomeação ou comissão de serviço? A isso nos respondem os artigos $8^{\circ}$ e $9^{\circ}$ da LGTFP.

$\mathrm{O}$ artigo $8^{\circ}$ da LGTFP enumera as situações em que o vínculo de emprego público se constitui por nomeação: missões genéricas e específicas das Forças Armadas em quadros permanentes; representação externa do Estado; informações de segurança; investigação criminal; segurança pública quer em meio livre quer em meio institucional e inspeção.

O artigo $9^{\circ}$ da LGTFP enumera as situações em que o vínculo de emprego público se constitui por comissão de serviço: cargos não inseridos em carreiras, designadamente cargos dirigentes e funções exercidas com vista à aquisição de formação específica, habilitação académica ou título profissional por trabalhador com vínculo de emprego público por tempo indeterminado. Concluindo, fora dos casos previstos nos artigos $8 .^{\circ}$ e $9 .^{\circ}$ da LGTFP, será celebrado um contrato de trabalho em funções públicas, respeitando-se assim, a regra geral prevista no artigo $7 .^{\circ}$ do mesmo diploma.

\section{A aproximação do regime do contrato de trabalho em funções públicas ao regime do Código de Trabalho}




\section{pontěditora}

O contrato de trabalho em funções públicas, o referido regime regra, também sofreu importantes alterações com a entrada em vigor da LGTFP.

$\mathrm{Na}$ verdade, é opinião unânime que outra das grandes alterações da LGTFP consiste na "convergência tendencial do regime dos trabalhadores públicos com o regime dos trabalhadores comuns, ressalvadas as especificidades exigidas pela função e pela natureza pública do empregador, com salvaguarda do estatuto constitucional da função pública" (Cláudia Nunes, 2014, p.11).

Prova disso é a LGTFP remeter diretamente a disciplina de algumas matérias para o Código do Trabalho, tornando este diploma fonte subsidiária do contrato de trabalho em funções públicas. E fá-lo de duas formas. Por um lado, através do artigo $4^{\circ}$ da LGTFP cuja epígrafe é, sem mais, “Remissão para o Código de Trabalho”, consagrando uma remissão geral para o Código do Trabalho (doravante CT) nas matérias que o próprio artigo elenca (e que são muitas!).

Acresce que, e como diz Cláudia Nunes (2014, p.12), “A L[G]TFP apenas reservou um regime próprio para as matérias que, devido às especificidades exigidas pela função e pela natureza pública do empregador, exigiam um tratamento diferenciado do regime privado". ${ }^{8}$ Ou seja, a aplicação das disposições do CT, ao abrigo desse artigo, não terá uma aplicação excecional, como à partida poderia parecer, mas aplicar-se-á, em grande parte das matérias constantes da LGTFP, conforme se pode ver pelas alíneas que enriquecem o referido artigo $4 .^{\circ}$ Por outro lado, e para além da remissão geral constante já do artigo $4 .^{\circ}$ da LGTFP, existem normas remissivas, dispersas e espalhadas, ao longo de toda a LGTFP - ex. artigo $16 .^{\circ}, 25 .^{\circ}$, $56^{\circ}, 101 .^{\circ}, 122 .^{\circ}, \ldots$

Apesar da aproximação clara entre estes dois regimes, quer pela consagração da remissão geral do artigo $4^{\circ}$ da LGTFP, quer pelas restantes normas remissivas dispersas ao longo do diploma, há uma diferença essencial que não foi alterada com a entrada em vigor da LGTFP.

\subsection{A competência dos tribunais administrativos e fiscais para dirimir litígios emergentes da constituição do vínculo de emprego público}




\section{pontěditora}

$\mathrm{Na}$ verdade, enquanto os litígios emergentes de relações jurídicas laborais privadas são dirimidos pelos juízos de trabalho; ${ }^{9}$ os litígios laborais emergentes de vínculo de emprego público estão, de acordo com o artigo $12^{\circ}$ da LGTFP, entregues aos TAF, "São da competência dos tribunais administrativos e fiscais os litígios emergentes do vínculo de emprego público." E, na verdade, já antes da entrada em vigor da LGTFP, o artigo 83. ${ }^{\circ}$ da LVCR, previa exatamente essa mesma atribuição de competências aos TAF. ${ }^{10}$

Ora, se o contrato de trabalho em funções públicas é, atualmente, o regime regra, cada vez mais semelhante ao que se encontra previsto no CT (recordemos a extensa remissão do artigo $4 .^{\circ}$ da LGTFP), surgem inevitavelmente preocupações: será razoável esta distinção, quando na prática estamos perante regimes materialmente muito semelhantes? Visto de uma outra perspetiva, encontram-se os TAF preparados para resolver conflitos com uma natureza predominantemente mais laboral do que público-administrativa?

Ciente desta questão esteve também o legislador. Na verdade, para o artigo $12^{\circ}$, até ao penúltimo anteprojeto da LGTFP, estava prevista uma redação completamente diferente da que aqui apresentamos e que foi abandonada na fase da concertação social. A sua redação dispunha que “1. São da competência dos tribunais de trabalho os litígios emergentes do vínculo de emprego público, sem prejuízo do disposto no número seguinte. 2. É da competência dos tribunais administrativos e fiscais a verificação da invalidade de vínculo de emprego público, que diretamente resulte da invalidade do ato administrativo no qual se fundou a constituição ou a modificação do mesmo”. Segundo Luís Almeida (2016, p.15), esta proposta foi abandonada "Porque, como assinalou recentemente FAUSTO DE QUADROS, houve uma forte oposição por parte dos membros da comissão da reforma do Código do Processo nos Tribunais Administrativos e do ETAF (já que esta solução divergia em toda a linha daquelas que a comissão pretendia alcançar com a Reforma do Contencioso Administrativo); e porque esta alteração gerou uma forte oposição por parte das estruturas sindicais em sede de concertação social". A redação atual é totalmente diferente, como já foi supra descrito.

Esta questão já foi denunciada na doutrina. Cláudia Nunes $(2014$, p.18), afirma que "Não obstante a aproximação do regime aplicável aos trabalhadores que exercem funções públicas ao regime laboral privado, os litígios emergentes do vínculo do emprego público continuam a ser resolvidos pelos tribunais administrativos e não, como sucede, nas relações jurídicolaborais privadas, pelos tribunais de trabalho”. Já Luís Almeida (2016, p. 16) sustenta, como soluções a este problema, que "Ou se mantém esta solução dualidade de jurisdição; Ou se 


\section{pontěditora}

transfere para a jurisdição administrativa e fiscal todo o Direito Laboral Administrativo, o que inclui todas as relações de trabalho inerentes ao exercício da função administrativa, independentemente dos respectivos estatutos e regimes jurídicos; Ou se transfere para a jurisdição dos tribunais de trabalho os litígios emergentes de vínculo de emprego público, ficando todo o Direito Laboral Administrativo debaixo da Jurisdição Comum.” A defender a primeira posição encontramos Pedro Madeira de Brito (2010, p. 496) "é inquestionável que os litígios emergentes das relações de trabalho subordinado na administração pública, constituídas por uma das formas previstas na LGTFP, devem ser submetidas aos tribunais da jurisdição administrativa”. A segunda posição é “claramente a solução defendida pela maioria da Doutrina, sendo defendida (de forma mais ou menos clara) por VASCO PEREIRA DA SILVA, VIEIRA DE ANDRADE, PAULO VEIGA E MOURA, ANA NEVES e BETTENCOURT DA CAMARA, e pela CGTP em sede de concertação social (no quadro da discussão do anteprojecto da LGTFP)." (Luís Almeida, 2016, p. 16). Para defesa desta posição são elencados, essencialmente, cinco argumentos: i) conjugação da alínea e) do número 1 do artigo 4. ${ }^{\circ}$ do ETAF com a alínea b) do número 4 do mesmo artigo do ETAF; ii) evitar o esvaziamento do foro administrativo; iii) os TAF serem processualmente mais céleres, na decorrência do respeito das especificidades administrativas e do sistema de organização judiciário; iv) os tribunais comuns proferirem decisões parciais, mais favoráveis aos empregadores e v) a inconstitucionalidade que poderá advir por desrespeito ao artigo $269 .^{\circ}$ da CRP, que traduz a existência de especificidades nas relações de emprego público. Por fim, a terceira posição que consistiria na "transferência de todo o Direito Laboral Administrativo para a jurisdição dos tribunais civis ou tribunais de trabalho, numa lógica em que se realça a natureza laboral dos contratos aqui em causa e em que se faz prevalecer o critério da similitude material das situações contratuais." (Luís Almeida, 2016, p. 19) ${ }^{11}$ é defendida por Palma Ramalho ${ }^{12}$ por ser uma solução que privilegia a i) similitude material das situações, ii) a especialização técnica dos juízos de trabalho para dirimir os litígios emergentes deste tipo de relações e iii) a redução dos conflitos de jurisdição existentes nesta matéria.

Mais do que compreender aquilo que a doutrina tem vindo a defender e as diversas posições existentes quanto a este tema, ${ }^{13}$ importa sobretudo perceber se a solução consagrada na atual LGTFP, que consistiu na manutenção do que já havia sido consagrado na LVCR, tem sido pacificamente aplicada pelos Tribunais. Ou seja, importa não apenas analisar a teoria, mas também aquilo que se tem vindo a registar na prática judicial. 


\section{pontěditora}

Para melhor refletir sobre estas questões, analisaremos, de seguida, alguma jurisprudência que demonstra bem as dificuldades por vezes sentidas neste campo e noutros com ele relacionados.

\subsection{As decisões contraditórias que têm surgido na jurisprudência}

A jurisdição dos tribunais judiciais é subsidiariamente definida na ordem jurídica portuguesa, conforme decorre do número 1 do artigo $211^{\circ}$ da CRP - “Os tribunais judiciais são os tribunais comuns em matéria cível e criminal e exercem jurisdição em todas as áreas não atribuídas a outras ordens judiciais." - bem como do número 1 do artigo $130^{\circ}$ da Lei $n^{\circ} 62 / 2013$, de 26 de agosto (LOSJ), ${ }^{14}$ ou ainda do artigo $64^{\circ}$ do Código do Processo Civil (CPC). ${ }^{15}$ Consequentemente, podemos dizer que a jurisdição dos tribunais judiciais é também definida por exclusão face aos TAF, ${ }^{16}$ ou seja, havendo normas que expressamente habilitem os TAF a dirimir certo tipo de litígios, serão esses (pelo menos formalmente e por decorrência legal) os tribunais competentes para tal.

Acontece que, apesar de no emprego público existirem normas específicas na legislação ordinária que atribuem competência aos TAF, nomeadamente o já referido artigo $12^{\circ}$ da LGTFP, ao qual devemos acrescentar a alínea b) do número 4 do artigo $4^{\circ}$ do Estatuto dos Tribunais Administrativos e Fiscais (doravante ETAF) "Ficam igualmente excluídas do âmbito da jurisdição administrativa e fiscal: d) A apreciação de litígios decorrentes de contratos de trabalho, ainda que uma das partes seja uma pessoa coletiva de direito público, com exceção dos litígios emergentes do vínculo de emprego público”, ainda assim, surgem na jurisprudência, conflitos de jurisdição negativos. O que não deixa de ser curioso e por isso podemos perguntar: numa questão que, à partida, parece tão bem delimitada (afinal a LGTFP e o ETAF parecem expressamente estipular a competência dos TAF para dirimir os litígios emergentes de vínculos de emprego público), porque será que, ainda assim, surgem tantos conflitos de jurisdição negativos nestas matérias?

$\mathrm{Na}$ verdade, aquilo que se tem vindo a verificar é que os TAF acabam por se considerar incompetentes para dirimir esses litígios porque isso comporta a aplicação de normas laborais, constantes do CT. Por sua vez, os juízos de trabalho, sem normas legais que os habilitem a julgar tais litígios, consideram-se incompetentes para dirimi-los já que, legalmente, essa esfera encontra-se expressamente atribuída aos TAF. 


\section{pontěditora}

\section{a) A relevância da configuração pelo Autor da relação jurídico-material e pedido para dirimir estes conflitos de jurisdição}

Exemplo disso é o Acórdão do Tribunal Central Administrativo Sul(“TCAS”) de 08 de novembro de 2007, proc. $\mathrm{n}^{\mathrm{o}}$ 00392/04. ${ }^{17}$ Em primeiro lugar o acórdão referido começa por clarificar que o conceito de jurisdição e competência são distintos, sendo possível definir o primeiro como "o poder de julgar genericamente atribuído, na organização do Estado, ao conjunto de tribunais" e o segundo como "a medida de jurisdição legalmente atribuída a cada um dos tribunais". Sabemos também que a competência varia em função de determinados critérios: matéria, valor, hierarquia e território. No caso em apreço importa a competência material.

A competência material dos TAF encontra-se no número 3 do artigo $212^{\circ}$ da CRP, mas também no ETAF, nomeadamente nos seus artigos $1^{\circ}, 3^{\circ}$ e $4^{\circ}$. Ora, para sabermos se a competência é dos TAF ou dos tribunais comuns, importa, em primeiro lugar, relembrar como é que a mesma se afere. Como diria Manual de Andrade (1979, p.91), "A competência do tribunal - ensina REDENTI - "afere-se pelo quiddisputatum (quiddecidendum, em antítese com aquilo que será mais tarde o quiddecisum"), é o que tradicionalmente se costuma exprimir dizendo que a competência se determina pelo pedido do Autor. "18

A competência apura-se então pelo pedido do Autor, não se fazendo qualquer tipo de juízo, nesse momento, acerca do seu mérito. Neste caso, o Tribunal Administrativo de Círculo de Lisboa, na primeira instância, decidiu julgar procedente a exceção de incompetência material porque o Autor não tinha provado a opção pelo regime jurídico de emprego público, ${ }^{19} \mathrm{e}$ baseavao seu pedido do Autor numa relação de natureza laboral de direito privado. Ao intentar a ação na jurisdição comum, também foi julgada procedente a exceção de incompetência material por se considerar que o Autor era um funcionário público e que a natureza da relação jurídica laboral era mista. Para este Tribunal nesses casos deve prevalecer "a natureza do vínculo naquilo que é inerente à natureza do provimento e não o vínculo na sua integralidade."

O Acórdão referido veio apoiar a decisão de incompetência material proferida pela jurisdição comum, concluindo que apesar do regime regra aplicável aos funcionários em causa ser o do direito privado, coexistia, ao mesmo tempo, para funcionários oriundos da Ex-Emissora Nacional, um regime de direito público, que emergia de uma relação jurídica de natureza administrativa. Não tendo isso sido alterado, o Autor mantinha uma relação de emprego público 


\section{pontěditora}

e não de direito laboral, pelo que essa relação só interessava "à justiça administrativa as relações jurídicas administrativas públicas, reguladas pelas normas de direito administrativo, passando em regra a determinação da competência por um critério material que assente na distinção material entre o direito público e o direito privado”. No mesmo sentido o Acórdão do Tribunal de Conflitos n. ${ }^{\circ}$ 11/05, de 8 de novembro de 2011, afirmou que "os trabalhadores oriundos da ex-EN, mantêm, um regime de direito público, pelo que deve concluir-se que os litígios relativos ao seu estatuto laboral emergem de uma relação jurídica de emprego público e não de uma relação laboral de direito privado."

Noutros Acórdãos, mais recentes, o Tribunal de Conflitos tem vindo a dizer o mesmo:"Se a questão do processo emerge de uma relação jurídica considerada de emprego público, é competente a jurisdição administrativa para apreciar e dirimir o litígio." - Cf. processo n. ${ }^{\circ}$ 056/13, de 16 de janeiro de 2014.

Por sua vez, e mais recentemente, no Acórdão n. ${ }^{\circ}$ 08/14, de 01 de outubro de 2015, o Tribunal de Conflitos concluiu em sentido oposto. Aqui o Autor requer ao Tribunal o reconhecimento da existência de uma relação laboral, regida pelo direito privado, entre si e a Universidade do Porto, ainda que a mesma tenha sido constituída por um contrato administrativo de provimento. E aqui conclui o Tribunal de Conflitos que "perante a pretensão expressa do Autor de reconhecimento da existência de um contrato individual de trabalho e não de uma relação de trabalho em funções públicas, não pode resolver-se a questão da competência em razão da matéria caracterizando tal relação como de contrato de trabalho em funções públicas em função da interpretação da evolução do regime jurídico em sentido contrário ao pretendido pelo Autor (sendo alheia ao objecto da presente decisão, repete-se, qualquer apreciação do acerto dessa solução)." No mesmo sentido ver ainda Acórdão do Tribunal de Conflitos n. ${ }^{\circ}$ 12/15, de 08 de março de 2017, Acórdão do Tribunal de Conflitos n. ${ }^{\circ}$ 017/16, de 17 de novembro de 2016 ou o Acórdão do Tribunal de Conflitos n. ${ }^{\circ}$ 07/17 de 07 de dezembro de 2017, onde se afirma expressamente que "Compete ao juízo do trabalho respetivo conhecer de contrato de trabalho, em funções públicas" já que "Se o autor fundamenta a ação tendo por base, em grande parte, numa relação laboral de direito privado, a competência para o julgamento do litígio, deve ser atribuída à jurisdição comum, por estar este expressamente excluído da jurisdição administrativa. Tanto mais que aos juízos do trabalho compete conhecer, em matéria cível, das questões que vêm elencadas sob as alíneas a) a s) do n. ${ }^{o} 1$ do art. 126. ${ }^{\circ}$ da LOSJ, mais concretamente: "b) Das questões emergentes de relações de trabalho subordinado(...); e n) Das questões entre sujeitos de uma relação jurídica de trabalho ou entre

$\mathbf{J}^{2}$ - Jornal Jurídico | Volume 1 | Número 1 


\section{pontěditora}

um desses sujeitos e terceiros, quando emergentes de relações conexas com a relação de trabalho, por acessoriedade, complementaridade ou dependência, e o pedido se cumule com outro para o qual o juízo seja diretamente competente". ${ }^{20}$

\section{b) A extensão da competência dos Juízos de Trabalho}

O Acórdão do Supremo Tribunal Administrativo (doravante "STA"), de 16 de junho de 2015, proc. 117/14.4TTLMG.C1.S1, considera mais uma vez que "A determinação do tribunal materialmente competente radica na estrutura da relação jurídica material submetida à apreciação do tribunal, segundo a versão apresentada pelo autor, isto é, tendo em conta a pretensão concretamente formulada e os respetivos fundamentos."

Sucede que, neste caso, o Autor configura o vínculo estabelecido com a entidade empregadora como um contrato individual de trabalho que, com a entrada em vigor do $\mathrm{n}^{\mathrm{o}} 2$ do $\operatorname{art} 17 .^{\circ}$ da Lei 59/2008, de 11/9, se teria transformado num contrato de trabalho em funções públicas, cujos litígios, como vimos, encontram-se legalmente atribuídos aos TAF.

O Supremo Tribunal Administrativo discordou então da decisão da Relação do Porto que considerou que a relação jurídico-laboral aqui em causa se tinha convolado, a partir de 1 de janeiro de 2009, num contrato de trabalho em funções públicas, isto porque "É certo que o $n^{\circ} 2$ do art. $17 .^{\circ}$ da $n^{\circ}$ Lei 59/2008, de 11/9, estabeleceu que a transição dos trabalhadores que, nos termos daquele diploma, se deva operar, designadamente das modalidades de nomeação e de contrato individual de trabalho, para a modalidade de contrato de trabalho em funções públicas é feita sem dependência de quaisquer formalidades".

Apesar do Tribunal também acolher como certo que "os Tribunais Administrativos são os competentes para apreciar os litígios emergentes desta relação jurídica de emprego público, norma que entrou em vigor em 01.01.2009, nos termos do preceituado no art. $118 .{ }^{\circ}, n^{\circ} 7, d a$ Lei 12-A/2008, e no art. 23. ' da Lei 59/2008.", acaba por concluir que "No entanto, vindo o A exercitar, por via desta acção, direitos que em grande parte se reportam a período anterior a 01.01.2009, nomeadamente a qualificação do contrato que vigorou até esta data, bem como o pagamento de férias, subsídios de férias e de Natal vencidos até àquela data, a jurisdição laboral é a competente para conhecer dos mesmos, por estar em causa uma relação de trabalho que ainda não se tinha convertido numa relação de natureza administrativa." Quanto ao período posterior em que o contrato individual de trabalho já se teria convolado num contrato de trabalho em funções públicas mantêm a competência nos atuais juízos de trabalho "não pode deixar de estender-se a competência do Tribunal do Trabalho, nos termos do art. 85. ${ }^{\circ}$, alínea 


\section{pontěditora}

o), da LOFTJ, ${ }^{21}$ pois a estes compete conhecer «das questões entre sujeitos de uma relação jurídica de trabalho ou entre um desses sujeitos e terceiros, quando emergentes de relações conexas com a relação de trabalho, por acessoriedade, complementaridade e dependência, e o pedido se cumule com outro para o qual o tribunal seja directamente competente»".

Não obstante, o Tribunal de Conflitos no Acórdão n. ${ }^{\circ}$ 07/17, de 7 de dezembro de 2017, já acaba por afirmar taxativamente que também "Compete ao juízo do trabalho respetivo conhecer de contrato de trabalho, em funções públicas, no qual se converteu, por força do artigo $17^{\circ} 2$ da Lei $n^{\circ} 59 / 2008$, de 11-09, o contrato individual de trabalho celebrado entre o autor e o réu, entidade empregadora, Instituto Nacional de Estatística, instituto público.", isto porque, ainda que o contrato seja, à data da propositura da ação (2015) um contrato de trabalho em funções públicas, “o autor fundamenta a ação tendo por base, em grande parte, numa relação laboral de direito privado, a competência para o julgamento do litígio, deve ser atribuída à jurisdição comum”.

\section{c) Acidentes de Trabalho}

No caso do Acórdão do Tribunal de Conflitos de 18 de junho de 2014, proc. $\mathrm{n}^{\circ}$ 050/13, ${ }^{22}$ a Autora foi admitida, através de um contrato de provimento, ao serviço na Caixa Geral de Depósitos. Nesse local sofreu um acidente de trabalho, de onde lhe advieram lesões. O Tribunal de Trabalho pronunciou-se no sentido de que não importa que a autora "esteja abrangida, na sua relação laboral, por um regime misto ou específico. Fundamental é que a Sinistrada celebrou, como a própria admite, um contrato de provimento, sendo beneficiária da Caixa Geral de Aposentações, com os inerentes direitos do regime da Função Pública, segundo o qual o regime jurídico dos acidentes de trabalho correm pelos Serviços Administrativos competentes, no caso a Caixa Geral de Aposentações”. Já o TAF do Porto considerou que, uma vez que a natureza jurídica da Caixa Geral de Depósitos tinha sido alterada pelo legislador no Decreto-Lei ${ }^{\circ}$ 287/93, de 20 de agosto, transformando-a numa empresa pública, aplicar-se-ia o regime do número 4 do artigo $2^{\circ}$ do Decreto-Lei $n^{\circ} 503 / 99$, de 20 de novembro e consequentemente seria o Código de Trabalho o regime aplicável. Na verdade, o Decreto-Lei n. ${ }^{o}$ 503/99, de 20 de novembro é aplicável a "a todos os trabalhadores que exercem funções públicas, nas modalidades de nomeação ou de contrato de trabalho em funções públicas, nos serviços da administração direta e indireta do Estado" (n. $\left.{ }^{\circ} 1\right)$, mas não é aplicável "Aos trabalhadores que exerçam funções em entidades públicas empresariais ou noutras entidades não abrangidas pelo disposto nos números anteriores é aplicável o regime de acidentes de 


\section{pontěditora}

trabalho previsto no Código do Trabalho" (n. $\left.{ }^{\circ} 4\right)$. Por esse mesmo motivo o TAF do Porto considerou que deveriam ser os juízos de trabalho a decidir a questão, uma vez que a trabalhadora em causa tinha sofrido um acidente de trabalho na CGD, uma empresa pública. A esta tese aderiu o Tribunal de Conflitos.

É curioso, no entanto, que uns meses antes, a 06 de fevereiro de 2014, o Tribunal de Conflitos tenha proferido outro acórdão (processo $\mathrm{n}^{\circ}$ 024/12), em que considera que no caso de uma entidade pública empresarial (doravante EPE) é competente a jurisdição administrativa para julgar uma ação interposta por um dos trabalhadores dessa entidade em virtude da incapacidade que sofreu num acidente de trabalho. A Autora, à data do acidente, exercia funções de assistente operacional no Centro Hospitalar de Lisboa Ocidental, EPE. Nessa data também era o Decreto-Lei no 503/99 de 20 de novembro o regime que regulava os acidentes de trabalho ocorridos ao serviço das entidades empregadoras públicas. Contudo, neste caso o tribunal considerou que a EPE integrava a administração indireta do Estado e por isso estava sujeita à disciplina dos números 1, 2 e 3 do Decreto-Lei referido. Estando sujeita a esse regime, os tribunais mais aptos a decidir a causa seriam os TAF.

Em janeiro de 2018, o Tribunal de Conflitos (processo n. ${ }^{\circ}$ 053/17) num caso semelhante aos acima identificados, considerou que os tribunais competentes para apreciar de um acidente de trabalho seriam os tribunais comuns, uma vez que o acidente tinha sido sofrido por um trabalhador a exercer funções para um município, mas no âmbito de um contrato "emprego-inserção" promovido pelo IEFP e o trabalhador em causa não tinha "um vínculo para o exercício de funções públicas nas modalidades de nomeação ou de contrato de trabalho em funções públicas, o acidente em causa não pode ser considerado como acidente em serviço". Sucede que ao abrigo do Decreto-Lei n. ${ }^{\circ}$ 143/2012, de 11 de julho, o IEFP, I. P., “é um instituto público de regime especial, nos termos da lei, integrado na administração indireta do Estado, dotado de autonomia administrativa, financeira e património próprio." - cf. número 1 do artigo 1. ${ }^{\circ}$ do Decreto-Lei referido. Pelo que, enquanto no caso anterior, o Tribunal de Conflitos considerou competentes os TAF por o acidente ter sucedido numa EPE que integrava a administração indireta do Estado; neste caso, e apesar do IEFP integrar tambéma administração indireta do Estado, curiosamente foram considerados competentes os juízos de trabalho. 


\section{pontěditora}

\section{Comentário à jurisprudência analisada}

Feito este retrato analítico facilmente se compreende que não é tarefa fácil conjugar, por um lado o artigo $12^{\circ}$ da LGTFP, a alínea b) do número 4 do artigo $4^{\circ}$ do ETAF e, por outro lado, o artigo $126^{\circ}$ da Lei de Organização do Sistema Judiciário ("LOSJ"). $\quad$ Na verdade, apesar de muitas vezes o vínculo de constituição de emprego ter uma natureza pública, as matérias tratadas estão sujeitas a um regime em todo semelhante, senão exatamente igual ao previsto no CT. Nestes casos, deve de facto questionar-se se os TAF terão a mesma sensibilidade para dirimir este tipo de litígios. Aliás, deve sobretudo refletir-se sobre estas matérias quando nos deparamos, em zonas de fronteira, com decisões jurisprudenciais proferidas em sentidos opostos. Os casos retratados no subcapítulo supra são exemplo disso.

Assim devemos, em primeiro lugar, questionar até que ponto o critério da configuração pelo Autor da relação jurídico-material e do pedido delimita, efetivamente, a jurisdição por que se devem julgar estes litígios (ponto a)).

$\mathrm{Na}$ verdade, este critério parece nem sempre ser respeitado, o que origina muitas vezes os conflitos de jurisdição que aqui, brevemente, descrevemos.

Assim, se por um lado os TAF acabam, muitas vezes, por atender à configuração jurídicomaterial que os Autores colocam nos seus requerimentos e petições iniciais; os juízos de trabalho, sem norma habilitante para julgar litígios provenientes de vínculos de emprego público, não relevam a forma como a pretensão é configurada pelos Autores e, consideram-se, também incompetentes.

Sucede que o critério de definir a jurisdição competente apenas pelo modo como o Autor configura o seu pedido e descreve a relação jurídico-material controvertida, pode não ser suficiente ou, melhor dizendo, pode dar origem a situações que colocam em xeque o princípio da igualdade.

Na verdade, sabendo isto de antemão, pode o Autor configurar essa relação jurídica ao abrigo do direito laboral privado e por isso serem os juízos de trabalho a dirimirem o litígio que traz à demanda; ou ao abrigo de um vínculo de emprego público e a sua pretensão ser dirimida pelos TAF. Ora, parece claro que a competência para determinar efetivamente quem dirime este tipo de litígios não pode ser assim tão volátil (sob pena de estarmos perante situações semelhantes, a serem dirimidas em jurisdições diferentes, apenas porque foram apresentadas pelos Autores, de formas diferente). 


\section{pontěditora}

Para além disso, importa ainda notar que, ao abrigo do antigo artigo $83 .^{\circ}$ da LVCR, os TAF eram competentes para dirimir litígios emergentes das "relações jurídicas de emprego público" - e daí, por exemplo, no primeiro acórdão analisado se terem considerado os mesmos competentes, ainda que o contrato em si fosse um contrato de provimento. Sucede que, atualmente, o artigo 12..$^{\circ}$ da LGTFP diz-nos que os TAF são competentes para dirimir litígios emergentes "do vínculo de emprego público".

Questionamo-nos se as expressões "vínculo de emprego público" e "relações jurídicas de emprego público" quererão dizer exatamente o mesmo ou se, pelo contrário, a segunda acaba por abranger mais situações - regidas, efetivamente, pelo direito público; mas não correspondentes aos vínculos de emprego público (a saber contrato de trabalho em funções públicas, nomeação e comissão de serviço). Seja por isso (ou não), a verdade é que desde a entrada em vigor da LGTFP, as decisões proferidas pelo Tribunal de Conflitos a considerar os TAF competentes para dirimir os litígios em questão são raríssimas (para não dizer inexistentes). Na verdade, a maior parte sustenta-se na forma como a relação jurídica é construída pelos Autores na petição inicial e não constando dela qualquer vínculo de emprego público, mas tão-só questões privado-laborais, o Tribunal de Conflitos tem acabado por considerar competentes os juízos de trabalho. Vejamos o recente Acórdão do Tribunal de Conflitos n. ${ }^{\circ}$ 065/17, de 17 de maio de 2018, que diz expressamente "Compete aos tribunais judiciais conhecer da acção em que se pede a declaração de ilicitude do alegado despedimento e a reintegração da Autora ao serviço de uma Freguesia quando o que se alegou não caracteriza um "contrato individual de trabalho da Administração Pública" ou um "contrato de trabalho em funções públicas", mas simplesmente e por defeito, um contrato individual de trabalho". Ou ainda o Acórdão do Tribunal de Conflitos n. ${ }^{\circ}$ 047/17, de 25 de janeiro de 2018, "Compete à jurisdição comum conhecer da acção em que a autora, invocando um direito emergente de um alegado contrato de trabalho a termo, visa fundamentalmente obter a condenação do outro contraente no pagamento de «créditos laborais» subsequentes ao seu «despedimento» ilícito."

Por este prisma, parece-nos que, em termos práticos, poderemos efetivamente já estar a assistir a um esvaziamento do foro administrativo no que concerne às competências para dirimir litígios de emprego público (ou porque os mesmos ultrapassam os vínculos de emprego público que analisamos; ou porque, prevalecendo o critério da relevância da construção da demanda e do pedido pelo Autor, os litígios serão, em grande parte dos casos, forçosamente considerados laborais - até porque se a LGTFP remete, em grande parte das matérias para o CT, os Autores, 


\section{pontěditora}

nas suas petições iniciais invocarão não as normas da LGTFP, mas sim as normas do CT).

Podem ainda surgir casos como os que vimos, no ponto b) do capítulo anterior, em que o Autor, na prática, configura os dois modos de relação - jurídico-privada e, a partir de um certo momento, jurídico-pública, e definirem-se critérios como os que vimos - porque o pedido do Autor incide mais sobre um período temporal em que o que estava subjacente era um contrato individual de trabalho, então devem os juízos de trabalho julgar o litígio em questão; e julgar não só esse pedido, como os pedidos feitos já na decorrência da existência e reconhecimento (por parte do próprio Autor) de um vinculo de emprego público.

Significa isto que se o Autor configurasse a ação, e nela abarcasse um lapso temporal maior sujeito a um vínculo de emprego público, seriam já os TAF os tribunais competentes para dirimir este litígio? E seriam também os TAF competentes para dirimir o período temporal em que as partes estavam vinculadas por um contrato individual de trabalho, sujeito ao direito privado? É que a norma prevista na alínea n) do n..$^{\circ} 1$ do artigo $126 .^{\circ}$ da LOSJ e que dá competência aos juízos de trabalho para dirimir "Das questões entre sujeitos de uma relação jurídica de trabalho ou entre um desses sujeitos e terceiros, quando emergentes de relações conexas com a relação de trabalho, por acessoriedade, complementaridade ou dependência, e o pedido se cumule com outro para o qual o juízo seja diretamente competente", não está igualmente prevista para os TAF. Pelo contrário, diz-se na alínea b), do número 4 do artigo $4 .^{\circ}$, que: "Estão igualmente excluídas do âmbito da jurisdição administrativa e fiscal: A apreciação de litígios decorrentes de contratos de trabalho, ainda que uma das partes seja uma pessoa coletiva de direito público”. Pelo que vimos no Acórdão do Tribunal de Conflitos n. ${ }^{\circ}$ 07/17, de 7 de dezembro de 2017, a resposta parece ser negativa. Na verdade, neste caso a Autora reclama créditos desde 2003 até 2015, tendo em vigor, entre 2003 e 2008, um contrato individual de trabalho que depois se transformou num contrato de trabalho em funções públicas - entre 2009 a 2015. Ora, mesmo vigorando por mais tempo a modalidade de contrato de trabalho em funções públicas (7 anos, em vez de 5), os juízos de trabalho foram considerados competentes para dirimir a ação. E mesmo tendo a ação sido proposta em 2015, em plena vigência da LGTFP.

Portanto, a questão não parece tão simples de resolver nem de delimitar, basta ver a diferença de posição do STA e do Tribunal de Conflitos que, futuramente, poderá gerar ainda mais conflitos de jurisdição.

Nos casos descritos no ponto c) do capítulo anterior, perante entidades claramente pertencentes ao setor empresarial do Estado, o Tribunal de Conflitos, em junho de 2014, considerou que os 


\section{pontěditora}

juízos de trabalho seriam os competentes para dirimir um caso de acidente de trabalho, apesar de em fevereiro do mesmo ano, ter considerado que a jurisdição competente era a administrativa. Tudo mudou com a interpretação que se fez acerca da natureza do empregador público: num caso considerou-se uma EPE como não fazendo parte da administração indireta e por isso sujeita ao regime do número 4 do artigo $2^{\circ}$ do referido Decreto-Lei; no outro caso já se considerou que fazia parte e por isso aplicou-se-lhe o regime previsto nos números 1,2 e 3 do artigo $2^{\circ}$ do Decreto-Lei $n^{\circ}$ 503/99, de 20 de novembro. E ainda mais insólito, no terceiro caso descrito, apesar do contrato ter sido celebrado com o IEFP, que integra a administração indireta do Estado, aqui os TAF já não seriam competentes, mas sim os juízos de trabalho. Porquê, pergunta-se, naturalmente. Mas carecem as respostas justificativas:mesmo perante entidades que integram o mesmo setor do Estado, há decisões diferentes por parte do Tribunal de Conflitos.

Ainda assim, independentemente das classificações que possam ser feitas acerca da natureza jurídica destas entidades, ${ }^{23}$ o que mais choca é saber que as situações em termos factuais são idênticas e que, apesar disso, um litígio pode acabar por ser atribuído aos TAF e outro aos juízos de trabalho.

É que o facto de se optar pela jurisdição comum num caso e noutro pela jurisdição administrativa comporta diferenças importantíssimas. E a consequência de um litígio ser dirimido por jurisdições diferentes pode chegar ao ponto de duas situações em tudo iguais terem um desfecho diferente, pondo-se desta forma em causa a segurança jurídica no nosso Estado de Direito. Na verdade, e como se afirma no Acórdão do Tribunal Central Administrativo do Sul, de 11 de abril de 2013, proc. no 07708/11, "é verdade que os tribunais administrativos e a legislação laboral pública é bem menos "flexivel" do que a legislação laboral "privada" aplicada nos tribunais judiciais do trabalho". Aqui diz-se ainda que na "resolução dos conflitos laborais através dos Tribunais Administrativos não podem ocorrer acordos[extrajudiciais, não pode haver recurso à equidade, nem ao abrigo da alínea d) do número 1 do artigo $180 .^{\circ}$ do CPTA recorrer-se à arbitragem quando estejam em causa direitos indisponíveis ou acidentes de trabalho], ao contrário do que se passa nos tribunais judiciais do trabalho”. Será que o facto da legislação laboral pública e administrativa ser mais rígida não cria situações de desigualdade face às questões julgadas nos juízos de trabalho (que são muitas vezes idênticas às questões que surgem nos TAF)? No acórdão em causa admite-se que "Quanto ao princípio da igualdade em sede de equiparação inovadora ao sector privado e em sede de tutela jurisdicional laboral como dantes, considera-se que, salvaguardando um núcleo

$\mathbf{J}^{2}$ - Jornal Jurídico | Volume 1 | Número 1 


\section{pontěditora}

material do que seja ser "servidor público", o vínculo laboral pode ser mais ou menos semelhante ao do trabalhador do sector privado. Tal núcleo não se nos mostra afetado”. No entanto, acaba por se concluir que a diferença de regimes (mais ou menos flexíveis) constitui "uma diferença justificada por haver aqui uma relação jurídica administrativa e ainda pelo tal núcleo material do servidor público plasmado nos artigos $266^{\circ}, 269^{\circ}, 271^{\circ}$ da CRP. Para situações distintas, remédios tutelares distintos".

Acontece que, nos casos aqui citados, as situações não pareciam de todos distintas, mas sim extremamente semelhantes. E sabemos que o princípio da igualdade se baseia na premissa de que devemos tratar o igual como igual e o desigual como desigual. Ele também se aplica na questão do acesso aos tribunais. Aliás, como nos diz Gomes Canotilho e Vital Moreira (2014, p. 346) "a vinculação da jurisdição pelo princípio da igualdade comporta três dimensões fundamentais: (a) igualdade de acesso dos cidadãos à jurisdição (art. 20-1); (b) igualdade dos cidadãos perante os tribunais; (c) igualdade de aplicação do direito aos cidadãos através dos tribunais (...) Finalmente a igualdade de aplicação do direito relaciona-se estreitamente com a vinculação jurídico-material do juiz ao princípio da igualdade. As manifestações mais relevantes são a aplicação de igual direito a casos idênticos (...)”. Ora, nos casos retratados parece haver dúvidas que o princípio da igualdade tenha sido respeitado, por se ter aplicado a duas situações concretamente idênticas uma jurisdição distinta.

Por fim, importa ainda equacionar, por que razão serão os TAF os tribunais (mais) competentes para dirimir questões referentes, por exemplo, às retribuições por desempenho de trabalho suplementar ${ }^{24}$ ou aos regimes de tempo de trabalho, ${ }^{25}$ quando estas matérias são constantemente trabalhadas pelos tribunais de trabalho e se regem, mesmo no emprego público, pelas disposições do CT? Mais, estas diferenças não colocarão em causa o acesso efetivo ao direito? De facto, não podemos esquecermo-nos que a efetividade no acesso ao direito exige sentenças adequadas às pretensões de tutela deduzidas em juízo, tribunais e recursos humanos especializados para estas matérias. E não parece que os tribunais administrativos estejam mais vocacionados para decidir nestes casos.

\section{Conclusões}

Resta-nos concluir e ponderar a adequação do artigo $12^{\circ}$ da LGTFP e da alínea b) do número 4 do $4 .^{\circ}$ do ETAF, atendendo ao quadro legislativo e jurisprudencial nacionais. Mais do que 


\section{pontěditora}

ponderar as diferentes posições doutrinais existentes nestas matérias, importa constatar aquilo que se tem verificado na prática jurisprudencial. Na verdade, pelo que aqui foi explanado, a redação atual do artigo $12^{\circ}$ da LGTFP cria inúmeros problemas para os tribunais. Têm frequentemente surgido conflitos de jurisdição, e a maior parte das vezes, negativos, o que significa que nem os tribunais administrativos nem os juízos de trabalho se consideram competentes para dirimir sobre matérias público-laborais. Claramente há um desconforto patente nos TAF quando confrontados com questões que, apesar de poderem ter como background um vínculo de emprego público, são, na prática, típicas das relações privadas laborais. Por outro lado, os tribunais comuns, sempre que se encontram perante uma relação jurídica nascida no seio do direito público afastam, de imediato, a sua competência, por não haver norma legal que os habilite a dirimir tais litígios.

Por sua vez, o Tribunal de Conflitos atribuicada vez maisa competência para dirimir os litígios emergentes de relações de emprego públicoaos juízos de trabalho fazendo-nos, parece, uma interpretação restritiva do artigo 12. da LGTFP e do artigo 4.\%/4/b) do ETAF. Há, claramente, um esvaziamento das competências dos TAF nestas matérias, que não pode ser ignorada.

Urge então resolver este problema. A penúltima redação do anteprojeto da LGTFP aproximouse de uma solução que poderia ter diminuído consideravelmente os conflitos negativos de jurisdição. Na verdade, considerava, regra geral, os tribunais de trabalho competentes para dirimir os litígios emergentes do vínculo de emprego público, exceto nos casos em que fosse necessária a verificação da invalidade do ato administrativo que fundou a constituição ou modificação do vínculo de emprego público. Esta solução parecia ser razoável, uma vez que aos tribunais de trabalho eram entregues as matérias reguladas pelo CT e aos tribunais administrativos cabiam as questões da invalidade dos atos administrativos, matéria que, por natureza, já lhes é inerente. ${ }^{26}$

Claro está que, nos juízos de trabalho, poderia efetivamente surgir algum desconforto com esta solução. Consideramos que, esse desconforto, a surgir, seria essencialmente na modalidade de constituição do vínculo de emprego público formadas por um ato unilateral da Administração Pública: a nomeação ou a comissão de serviço. Em relação ao contrato de trabalho em funções públicas, atendendo à semelhança que assume para com o típico contrato de trabalho privado, ${ }^{27}$ não cremos existirem razões para esse desconforto se verificar. ${ }^{28}$ Pelo que, a admitir-se alguma alteração a redação do anteprojeto, seria no sentido de manter a atribuição de competência aos tribunais de trabalho para dirimirem sobre contrato de trabalho em funções públicas e restringi- 


\section{pontěditora}

la nas modalidades de nomeação e comissão de serviço. Assim, aos TAF caberia tudo aquilo que possivelmente estivesse relacionado com o ato unilateral emitido pela AP (e não apenas a sua invalidade, mas também procedimento administrativo de constituição, alteração e execução). Tudo o que, ainda que perante um ato unilateral, se reportasse materialmente a matéria laboral, caberia na mesma aos juízos de trabalho. ${ }^{29}$

Somos da opinião proferida por Palma Ramalho de que deverá ter-se em conta a similitude das situações (independentemente do vínculo que lhes deu origem) e que os juízos de trabalho se encontram, tecnicamente, mais preparados para dirimir este tipo de litígios. Optando por esta solução deixaria de existir qualquer conflito para com as normas do ETAF e reduzir-se-iam, e muito, os conflitos negativos de jurisdição, tal como ficou aqui claro. No fundo, assumir-se-ia aquilo que nos parece que já acontece na prática - o esvaziamento do foro administrativo nestas matérias. A manutenção de uma solução que não corresponde à realidade jurisprudencial não pode sobreviver por se considerar que os TAF são mais céleres que os juízos de trabalho (o queatendendo, mais uma vez, à prática quotidiananão parece de todo corresponder à verdade) ou por se considerar que os juízos de trabalho são "menos parciais". Do artigo $269 .^{\circ}$ da CRP não parece constar qualquer impedimento a esta solução, prevalecendo, sem dúvida aqui, o princípio da igualdade, previsto no artigo $13 .^{\circ}$. Na verdade, a especialidade do regime da função pública prevista no artigo $269 .^{\circ}$ da CRP não é colocada em causa quando o conteúdo material das relações é similar, no sentido de ser privado-laboral e regido por normas do CT. Aliás é a própria LGTFP a reconhecer, em muitas matérias, que os direitos e obrigações dos trabalhadores com vínculo de emprego público (e até mesmo o interesse público) ficam (bem) assegurados pelo direito laboral privado, remetendo para o mesmo.

Enfim, resta concluir que, adotando uma solução dentro dos moldes da aqui explicada, e que podia bem ser a plasmada na redação prevista até ao último anteprojeto da LGTFP, haveria certamente uma redução dos conflitos de jurisdição que até então temos assistido, bem como o risco de serem desrespeitados princípios fundamentais do nosso ordenamento jurídico, quer seja o do acesso aos tribunais (com recurso a justiça efetiva e de qualidade) quer o do princípio da igualdade.

Por fim, resta acrescentar que o anteprojeto do novo ETAF prevê a criação, no artigo 44. ${ }^{\circ}$-A, de juízos administrativos especializados, nomeadamente, na alínea b), a criação de um “juízo administrativo social" a quem compete "conhecer de todos os processos relativos a litígios em matéria de emprego público e da sua formação, ou relacionados com formas públicas ou privadas de proteção social, exceto os relativos ao pagamento de créditos laborais por parte 


\section{pontěditora}

do Fundo de Garantia Salarial”. Se esta solução se concretizar, acreditamos que poderá diminuir as nossas reservas da competência para litígios emergentes de vínculo de emprego público estarem entregues aos TAF, sobretudo no que concerne à questão da técnica/especialização dos magistrados; mas isso, ainda assim, não resolve todos os outros problemas que apontamos de interpretação da lei e garantia do respeito pelos princípios constitucionais de igualdade e acesso (efetivo à justiça).

\section{Notas de rodapé}

1 Que tanto podem ser direitos, liberdades e garantias como direitos económicos, sociais e culturais.

2 Exemplo de um direito, liberdade e garantia presente no artigo $53^{\circ}$ da CRP

3 Exemplo de um direito económico, social e cultural constante do artigo $58^{\circ}$ da CRP.

4 Consagrado no artigo $20^{\circ}$ da CRP.

5 Para além do vínculo de emprego prevê-se na LGTFP, mais concretamente no número 1 do artigo $6^{\circ}$ e no artigo $32^{\circ}$, a possibilidade do trabalho em funções públicas poder ser prestado mediante um contrato de prestação de serviços, situação que já é alvo de críticas doutrinais, no sentido de se considerar que a LGTFP apenas deveria tratar das relações laborais onde existe subordinação jurídica.

6 Conforme consta expressamente do número 3 do artigo $6^{\circ}$ da LGTFP.

7 Lei n. ${ }^{\circ} 12-\mathrm{A} / 2008$, de 27 de fevereiro. 
8 É o caso do recrutamento de trabalhadores, a cessação do vínculo do trabalho em funções públicas, a estruturação de carreiras, a mobilidade, a cedência do interesse público, o estatuto remuneratório, o exercício do poder disciplinar, os direitos, deveres e garantias de imparcialidade dos trabalhadores em funções públicas.

9 Como decorre do artigo $126^{\circ}$ da Lei $n^{\circ} 62 / 2013$, de 26 de agosto

$10 \mathrm{O}$ artigo $83 .^{\circ}$ da LVCR já afirmava que "Os tribunais da jurisdição administrativa e fiscal são os competentes para apreciar os litígios emergentes das relações jurídicas de emprego público."

11 A solução adotada no sistema italiano.

12 Posição formulada oralmente em sessão subordinada ao tema «Contrato a termo na Lei Geral do Trabalhoem Funções Públicas» integrada no âmbito da Conferência «Contrato de Trabalho a Termo: Flexibilidade vs Precariedade», organizada pelo Instituto de Direito do Trabalho e que decorreu na Faculdade de Direito da Universidade de Lisboa no dia 30 de Outubro de 2014.

13 Para aprofundar mais as posições doutrinais cf., ainda, Lourenço Vilhena de Freitas, $O$ contencioso sobre a execução do Contrato de Trabalho em Função Públicas no Anteprojecto da Lei Geral do Trabalho em Funçães Publicas, disponível em https://www.icjp.pt/sites/default/files/papers/contencioso da_execucao dos_contratos_no_anteprojecto da_lei geral_do_trabalho_em funcoes_publicas.pdf

14 Alínea a) do número 1 do artigo $130^{\circ}$ da LOSJ "Preparar e julgar os processos relativos a causas não atribuidas a outra secção da instância central ou tribunal de competência territorial alargada".

15 Artigo $64^{\circ}$ do CPC "São da competência dos tribunais judiciais as causas que não sejam atribuídas a outra ordem jurisdicional".

16 Cf. número 3 do artigo 212. ${ }^{\circ}$ da Constituição da República Portuguesa.

17 Todos os acórdãos referidos ao longo deste artigo estão disponíveis em www.dgsi.pt.

18 Esta posição é aceite pelos tribunais. Veja-se por exemplo, o Acórdão do Supremo Tribunal Administrativo de 11 de julho de 2000 , recurso ${ }^{\circ} 318$.

19 Exigido na altura de acordo com o número 4 do artigo $59^{\circ}$ do Decreto-Lei no 167/84, de 22 de maio.

20 E o mesmo se tem vindo a dizer no próprio Supremo Tribunal de Justiça (Proc. n. ${ }^{\circ}$ 492/09.2TTPRT.P1.S1, de 30/03/2011; Proc. n. ${ }^{\circ}$ 204/11.0TTVRL.P1.S1, de 12/09/2013; Proc. 2596/11.2TTLSB.L1.S1, de 18/06/2014.)

21 Atual alínea n) do número 1 do artigo 126.․a LOSJ.

22 Aqui, mais uma vez, estávamos perante um conflito negativo de jurisdição.

23 E sabemos que a Caixa Geral de Depósitos levanta algumas opiniões divergentes, sendo pacífico, no entanto que se encontra integrada no setor empresarial do estado (onde se incluem as empresas públicas e as entidades públicas empresariais).

24 P.ex. artigo $120^{\circ}$ da LGTFP

25 P.ex. artigo $126^{\circ}$ da LGTFP

26 Artigo $50^{\circ}$ do Código do Processo nos Tribunais Administrativos

27 Patente no capítulo 3 deste trabalho.

28 E fora dos vínculos de emprego público, certamente o contrato de prestação de serviços não seria também novidade para os tribunais de trabalho.

29 Claro está que, matérias como o recrutamento e procedimentos concursais teriam também que ser sempre entregues aos TAF. Mas aqui estamos a falar de uma fase anterior à constituição do vínculo de emprego público. 
pontěditora

\section{Referências bibliográficas}

\section{Legislação}

Código de Processo Civil

Código de Processo dos Tribunais Administrativos

Código do Trabalho

Constituição da República Portuguesa 


\section{pontěditora}

Decreto-Lei no 503/99, de 20 de novembro

Decreto-Lei nº 287/93, de 20 de agosto

Decreto-Lei n. ${ }^{\circ}$ 143/2012, de 11 de julho

Estatuto dos Tribunais Administrativos e Fiscais (e seu Anteprojeto)

Lei de Organização do Sistema Judiciário

Lei dos Vínculos, Carreiras e Remunerações

Lei Geral do Trabalho em Funções Públicas

Proposta de Lei n. ${ }^{\circ} 184 / X I I$

\section{Obras}

Almeida, Luís Filipe Mota (2016). Notas breves sobre o Âmbito da Jurisdição Administrativa

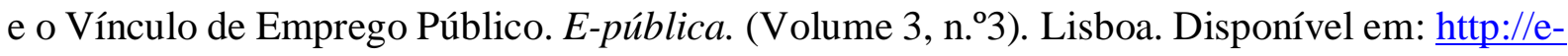
publica.pt/volumes/v3n3a13.html.

Andrade, Manuel De (1993). Noções Elementares de Processo Civil.Coimbra: Coimbra Editora.

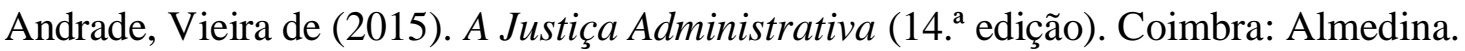

Brito, Pedro Madeira de (2010). Contrato de Trabalho da Administração Pública e sistema de fontes. Lisboa.

Canotilho, Gomes \& Moreira, Vital (2014). Constituição da República Anotada, Artigos $1^{o} a$ $107^{\circ}$ (Vol.I). Coimbra: Coimbra Editora,

Freitas, Lourenço Vilhena de. O contencioso sobre a execução do Contrato de Trabalho em Função Públicas no Anteprojecto da Lei Geral do Trabalho em Funções Publicas. Disponível em:

https://www.icjp.pt/sites/default/files/papers/contencioso_da_execucao_dos_contratos_no_ant eprojecto_da_lei_geral_do_trabalho_em_funcoes_publicas.pdf.

$\mathrm{J}^{2}$ - Jornal Jurídico | Volume 1 | Número 1 


\section{ponteditora}

Martins, David Carvalho \& Coelho, Susana Santos. (2017). A tutela dos direitos dos trabalhadores na Administração Pública nos Tribunais Administrativos e nos Tribunais de Trabalho em sede de acidentes de trabalho e doenças profissionais. Coleção Formação Contínua Direito do Trabalho na Administração Pública (Vol. I). Disponível em: http://www.cej.mj.pt/cej/recursos/ebooks/Administrativo_fiscal/eb_Direito_do_Trabalho_na_ Administracao_Publica_I.pdf.

Miranda, Jorge \& Medeiros, Rui (2007). Constituição da República Portuguesa, Tomo III. Coimbra: Coimbra Editora.

Neves, Ana Fernanda (2006). O Contrato de Trabalho na Administração Pública.Estudos em homenagem ao Professor Doutor Marcello Caetano no centenário do seu nascimento / ed. lit.(Vol. I.). Faculdade de Direito da Universidade de Lisboa. Coimbra: Coimbra Editora.

Nunes, Cláudia Sofia Henriques (2014). O Contrato de Trabalho em Funções Públicas face à lei geral do trabalho ( $1^{\mathrm{a}}$ edição). Coimbra: Coimbra Editora.

Pires, Miguel Lucas (2016). Lei Geral do Trabalho em Funções Públicas, Anotada e Comentada.Almedina.

Silva, Vasco Pereira da (2016). O Contencioso Administrativo no Divã da Psicanálise - Ensaio sobre as Acções no Novo Processo Administrativo(Reimpressão da 2. ${ }^{a}$ edição). Coimbra: Almedina.

\section{Jurisprudência (todos disponíveis em:www.dgsi.pt)}

Acórdão do Tribunal de Conflitos (03 de julho de 2003). Proc. n. ${ }^{\circ}$ 013/03.

Acórdão do Tribunal Administrativo Central Sul (08 de novembro de 2007). Proc. $\mathrm{n}^{\circ}$ 00392/04.

Acórdão do Tribunal de Conflitos (8 de novembro de 2011).Proc. n. ${ }^{\circ}$ 11/05.

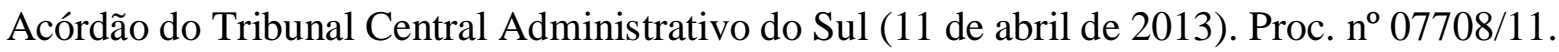

Acórdão do Tribunal de Conflitos (20 de junho de 2013). Proc. n. ${ }^{\circ} 022711$,

Acórdão do Tribunal de Conflitos (16 de janeiro de 2014). Proc. n. ${ }^{\circ}$ 056/13.

Acórdão do Tribunal de Conflitos (06 de fevereiro de 2014). Proc. nº 024/12.

$\mathrm{J}^{2}$ - Jornal Jurídico | Volume 1 | Número 1 


\section{pontěditora}

Acórdão do Tribunal de Conflitos (18 de junho de 2014). Proc. nº 050/13.

Acórdão do Supremo Tribunal Administrativo (16 de junho de 2015). Proc. 117/14.4TTLMG.C1.S1.

Acórdão do Tribunal de Conflitos (01 de outubro de 2015) Proc. n. ${ }^{\circ}$ 08/14.

Acórdão do Tribunal de Conflitos (17 de novembro de 2016)Proc. n. ${ }^{\circ}$ 017/16.

Acórdão do Tribunal de Conflitos (08 de março de 2017). Proc. n. ${ }^{\circ 012 / 15 . ~}$

Acórdão do Tribunal de Conflitos (07 de dezembro de 2017). Proc. n. ${ }^{\circ}$ 07/17.

Acórdão do Tribunal de Conflitos (25 de janeiro de 2018). Proc. n. ${ }^{\circ}$ 053/17.

Acórdão do Tribunal de Conflitos (17 de maio de 2018). Proc. n. ${ }^{\circ}$ 065/17. 